\title{
PENGARUH SUPERVISI DAN DUKUNGAN TUGAS (TASK SUPPORT) TERHADAP ORGANIZATIONAL CITIZENSHIP BEHAVIOR (OCB) GURU SMP NEGERI DI KABUPATEN HALMAHERA SELATAN PROVINSI MALUKU UTARA
}

\author{
Halifat Wahid*
}

\begin{abstract}
The objective of the reserach was to find out the influence from supervision and TaskSupport toward organizational citizenship behavior (OCB) of Teachers. The research took place at State Junior High School of South Halmahera, North Maluku Province.. The Research used random sampling and path analysis as its technical ways. The sample of the research were 91 teachers of state Junior High School. The result of the reserach showed that supervision has positif effect (1) supervision has direct effect to orgnizational citizenship behavior (OCB), (2) task support has positif effect to organizational behavior (OCB), (3) supervison has positif direct effect to task support. Therefore, The Research concluded that organizational citizenship behavior $(O C B)$ teachers could upgrade themselves well if the supervison could work great and supported by qualified task support.
\end{abstract}

Key words: OCB, Supervision and Task Support.

\section{PENDAHULUAN}

Pendidikan merupakan faktor penting dalam meningkatkan kesejahteraan hidup seseorang. Bahkan dengan pendidikan, suatu bangsa akan dapat membebaskan diri dari belenggu kemiskinan dan berdiri kokoh diantara bangsa-bangsa lain. Begitu pentingnya peranan pendidikan dalam suatu bangsa sehingga pendidikan perlu dipandang sebagai kebutuhan, bukan sebagai pelengkap hidup saja. Oleh karena itu sudah selayaknya pendidikan mendapatkan perhatian khusus semua pihak, terutama dari pemerintah sebagai penyelenggara negara. Menteri Pendidikan dan Kebudayaan dalam peringatan hari guru Nasional tanggal 25 November 2012 mengamanatkan bahwa pendidikan merupakan sistem rekayasa sosial terbaik untuk meningkatkan kesejahteraan, keharkatan dan kemartabatan suatu bangsa, di mana guru merupakan tonggak utama dalam dunia pendidikan. Untuk itu, sangatlah tepat, bahwa guru di jadikan sebagai profesi yang harus mendapatkan kesempatan untuk mengembangkan profesionalitasnya, mendapatkan perlindungan dan jaminan kesejahteraan.

Pendidikan di Indonesia masih dirasa belum berhasil mewujudkan cita-cita pendidikan yang tertuang dalam UU No 20 tahun 2003. Pada tahun 2011, berdasarkan data dalam Education For All (EFA) Global Monitoring Report 2011: The Hidden Crisis, Armed Conflct and Education, yang dikeluarkan oleh UNESCO, peringkat pendidikan di Indonesia, turun menjadi peringkat ke-69 dari peringkat ke-65 tahun 2012.

Banyak faktor penyebab kegagalan pendidikan di Indonesia, mulai dari angka putus sekolah, buruknya infrastruktur hingga kurangnya mutu guru. Tetapi masalah utama pendidikan di Indonesia adalah kualitas guru yang masih rendah, kualitas kurikulum yang belum standar, dan kualitas infrastruktur yang belum memadai. Disamping itu, banyak sekali muncul keluhan guru tentang ketentuan mengajar minimal 24 jam setiap minggu yang diatur dalam PP 74/2008. Ada tiga variabel yang

\footnotetext{
* Guru SMP Negeri di Kabupaten Halmahera Selatan, Provinsi Maluku Utara
} 
harus di evaluasi terkait dengan kinerja guru. Pertama adalah absentisme, kedua prestasi siswa, dan ketiga sampai sejauh mana peran guru dalam membangun budaya belajar di sekolah.

Dari kenyataan tersebut mengindikasikan bahwa guru selama ini hanya berusaha untuk megerjakan tugas-tugas formal (intra-role), dan belum tersentuh untuk melakukan tugas-tugas di luar tanggung jawabnya (extra-role). Padahal dalam penelitian, perilaku extra-role atau sering disebut Organizational citizenship Behavior (OCB), sangat penting dalam mendukung kemajuan organisasi, karena OCB merupakan perilaku yang melampaui panggilan tugas dan dilakukan secara sukarela.

Secara umum kurangnya OCB guru SMP Negeri di Kabupaten Halmahera Selatan diketahui dari munculnya perasaan ego di Satuan Perangkat Daerah (SKPD), sehingga Bupati Halmahera Selatan menginstruksikan masing-masing Satuan Kerja Perangkat Daerah (SKPD) agar dalam melaksanakan tugasnya tidak mengedepankan ego sektoral. Selain itu, indikasi kurangnya OCB guru disimak dari sambutan Sekretaris daerah Kabupaten Halmahera Selatan pada peringatan hari pendidikan nasional tahun 2012, yang mengatakan bahwa keseriusan guru dalam proses belajar mengajar belum sepenuhnya dilakukan dengan baik

Upaya untuk menstabilkan keseriusan guru, salah satunya dengan melelang jabatan Kepala Sekolah. Tujuannya sebagaimana dinyatakan oleh Kadis Pendidikan dan Kebudayaan Kabupaten Halmahera Selatan bahwa upaya melelang jabatan Kepala Sekolah dilakukan untuk menstabilkan kondisi sekolah, karena guru dan Kepala sekolah belum maksimal menjalankan tugas masing-masing dengan baik. Guru sebagai panutan disekolah perlu menegakkan sikap prioritasnya melalui sikap kedisiplinan, sportivitas dan tanggung jawab. Sebaliknya Kepala Sekolah harus memahami tugasnya sebagai seorang pemimpin, sehingga sekolah akan lebih efektif.

\section{Organizational Citizenship Behavior OCB}

Luthans (2011: 149) mendefinisikan OCB sebagai, “OCB as "individual behavior that is discretionary, not directly or explicitly recognized by the formal reward system, and that in the aggregate promotes the effective functioning of the organization". OCB sebagai perilaku individu yang bersifat bebas, yang tidak secara langsung dan eksplisit mendapat penghargaan dari sistem imbalan formal, dan yang secara keseluruhan mendorong keefektifan fungsi-fungsi organisasi. Sedangkan Jones (2008:95) mengatakan, "organization citizenship behavior (OCB ) is behavior that is above and beyond the call of duty that is behavior that is not required of organizational members but is nonetheless necessary for organizational survival and effectiviness". OCB adalah perilaku yang melebihi panggilan tugas di mana merupakan perilaku yang tidak di perlukan oleh anggota organisasi tetapi penting bagi kelangsungan hidup dan efektivitas organisasi. Robbins dan Coulter (2012:373) menyebutkan OCB sebagai, "organizational citizenship behavior (OCB) is discretionary behavior that's not part of an employee's formal job requirements, but which promotes the effective functioning of the organization". OCB adalah perilaku memilih yang bukan bagian dari persyaratan kerja formal karyawan, tapi dapat mempromosikan fungsi efektif dari organisasi. Definisi yang sama juga dikemukakan Steve M. Jex (2002:114) yang mengatakan bahwa, "although it can take several forms, OCB is defined as behavior that is not part of employees' formal job responsibilities. Para ahli berfariasi dalam memaparkan dimensi-dimensi dari OCB. misalnya: Organ mengkategorikan 5 dimensi yaitu: Altruism, Courtesy, Sportsmanship, Conscientiousness, dan Civic virtue. Arnold mengatakan 3 dimensi OCB, yaitu: Conscientiousness, Courtesy, dan Sportsmanship. 
Sementara Podsakof, et al, mengatakan Tujuh tema umum atau dimensi pada OCB antara lain: "Helping Behavior, Sportsmanship, Organizational Loyalty, Organizational Compliance, Individual Initiative, Civic Virtue, and Self Development".pendapat lain disampaikan Farh yang mengkategorikan OCB kedalam Sembilan bentuk antara lain: “...Altruism, Conscientiousness, Sportsmanship, Courtesy, Civic Virtue, Functional Participation, Advocacy Participation, Loyalty and Voice".

Berdasarkan konsep di atas dapat disintesiskan Organizational Citizenship Behavior (OCB) adalah perilaku yang melampaui tugas formal yang dilakukan secara sukarela, dan berkonstribusi positif terhadap organisasi, dengan indikator: membantu orang lain (altruisme), kesadaran untuk bekerja melebihi tugas (Conscientiousness), sportivitas (Sportsmanship), kesopanan (courtesy), berpartisipasi dalam kehidupan organisasi (civic virtue), memberi saran kontruktif (making contructive), loyalitas (loyalty) dan taat terhadap aturan (Advocacy Participation).

\section{Supervisi}

Menurut pendapat Caruso (2007:76), "we believe that supervision is a reciprocal process by which the supervisor and the teacher influence each other's behavior". Kita menyadari bahwa supervisi adalah proses timbal balik, di mana supevisor dan guru dapat mempengaruhi perilaku masing-masing. Lebih lanjut Caruso (2007:6-7) mengatakan, "supervision as skilled management through which caregivers improve performance and grow professionally is distinct from that which is self-serving and paternalistic". Definisi ini sejalan dengan Borders \& Brown (2005:71) yang mengatakan, "supervision is evaluative, there is a power differential in the relationship, and supervisees typically are quite invested, personally, in their work". Supervisi juga di maknai sebagai bentuk evaluatif, sehingga ada kekuatan yang diferensial dalam hubungan, dan di supervisi biasanya cukup di investasikan, secara pribadi, dalam pekerjaan mereka. Sullivan (2009:4) secara spesifik memaknai supervisi sebagai, "supervision is the process of engaging teachers in instructional dialogue for the purpose of improving teaching and increasing student achievement". Supervisi adalah proses melibatkan guru dalam dialog untuk meningkatkan pengajaran dan prestasi siswa. Sedangkan Bailey (2006:340) mendefinisikan supervisi, "supervision is a process of overseeing theability of people to meet the goals of the organization in which they work". Supervisi adalah proses mengawasi kemampuan orang untuk memenuhi tujuan organisasi di mana mereka bekerja. Sedangkan Kimbal Willes (1956:4) menyimpulkan supervisi: supervision exist to help teacher to do their jobs better". Supervise adalah untuk membantu guru melakukan pekerjaan yang lebih baik. Sergiovanni (2002:xvi) mengatakan: Supervision is an activity that involves another in supporting and furthering that caring for the learner and respect for the significance of what is taught. Supervisi adalah kegiatan yang melibatkan orang lain dalam mendukung, memajukan dan memlihara pelajar untuk menghormati betapa pentingnya apa yang diajarkan.

Dari deskripsi beberapa konsep di atas, maka dapat disintesiskan bahwa Supervisi adalah suatu proses membantu pegawai dalam melaksanakan tugas secara efektif dengan indikator: Memberi bantuan, memberi bimbingan, memberi arahan, melakukan pemantauan, dan melakukan evaluasi

\section{Dukungan Tugas (task support)}

Sonnentag (2002:454):memaknai task support sebagai berikut: "task support the extent to which employees perceive that they are being supplied with the materials, equipment, 
services, and resources necessary to perform their jobs". Dukungan-tugas (task support) sejauh mana karyawan merasa bahwa mereka sedang disediakan dengan bahan, peralatan, jasa, dan sumber daya yang diperlukan untuk melakukan pekerjaan mereka. Statemen ini dapat diketahui bahwa unsur terpenting dalam dukungan tugas (task support) adalah ketersediaan bahan, peralatan, jasa dan sumber daya yang dibutuhkan karyawan agar mereka dapat melakukan pekerjaan dengan benar. Artikel yang ditulis oleh Iize Zigurs, yang berjudul "A Theory of Task/Technology Fit and Group Support Systems Effectiveness" terbitan USA: University of Colorado,1998 halaman 313, mengutip pendapat Nunamaker, Dennis, Valacich, Vogel, dan George menyatakan: "process support, process structure, task support, and task structure, overall categories are not defined; each element of classification basis is further described (e.g., process support includes parallel communication, group memory, and anonymity). Dukungan proses, struktur proses, dukungan tugas, dan struktur tugas, kategori keseluruhan tidak didefinisikan, akan tetapi yang dijelaskan klasifikasi setiap elemen dasar (misalnya, dukungan proses meliputi komunikasi paralel, memori kelompok, dan anonimitas).

Artikel yang ditulis oleh lize Zigurs ini juga mengutip pendapat Fjermestad (forthcoming) yang menyatakan: Communication mode, design, process structures, and task support, overall categories are not defined; each element of classification basis is further described (e.g., communication mode might be voice, text, video, etc.). Modus komunikasi, desain, struktur proses, dan dukungan tugas, kategori keseluruhan tidak didefinisikan, klasifikasi masing-masing unsur dasar yang dijelaskan (misalnya, modus komunikasi mungkin suara, teks, video, dll).Neustrom (2011:184) munguraikan dukungna tugas (task support) dengan mengatakan: "there is a supervisor here in the western area who is the epitome of a leader the reason he cares. He cares about people (psychological support) and about getting the job done right (task support)". Ada seorang supervisor di sini di wilayah barat yang merupakan lambang pemimpin, alasannya dia peduli. Dia peduli tentang orangorang (dukungan psikologis) dan tentang mendapatkan pekerjaan dilakukan dengan benar (dukungan tugas).

Neustrom (2011:183) mengatakan, “...they provide task support when they help assemble the resources, budgets, power, and other elements that are essential to get the job done". Mereka memberikan dukungan tugas ketika mereka membantu menyediakan sumber daya, anggaran, kekuasaan, dan elemen lain yang penting untuk mendapatkan pekerjaan yang dilakukan. Sementara Faruk Şahin (2011:4), menyatakan bahwa : "...task support may also provide resources in the forms of materials, technology, or work equipment". Dukungan tugas juga dapat memberikan sumber daya dalam bentuk bahan, teknologi, atau peralatan kerja.

Dari beberapa konsep di atas, maka dapat disintesiskan bahwa dukungan tugas (Task Support) adalah: kepedulian supervisor terhadap kebutuhan pekerjaan karyawan, agar karyawan dapat melakukan pekerjaan dengan benar, dengan indikator: menyediakan bahan, menyediakan peralatan, menyediakan jasa dan menyediakan sumber daya.

\section{METODE}

Penelitian ini dilaksanakan pada SMP Negeri di Kabupaten Halmahera Selatan, provinsi Maluku Utara, dengan unit analisis adalah guru yang berstatus pegawai negeri yang mengajar di SMP Negeri di Kabupaten Halmahera Selatan. Waktu penelitian berlangsung bulan Juni 2012 sampai Juli 2012. Penelitian ini menggunakan metode survey dengan menggunakan pendekatan analisis jalur. Populasi terjangkau sebanyak 117 orang guru. Sampel sebanyak 91. Metode yang digunakan dalam penelitian ini 
adalah metode survey dengan menggunakan kuesioner sebagai alat pengumpulan data. Sebelum kuesioner digunakan dalam penelitian ini, terlebih dahulu dilakukan ujicoba untuk menentukan validitas dan reabilitas instrumen. Hasil tersebut digunakan sebagai instrumen untuk mengambil data dalam penelitian di lapangan. Analisis data meliputi: 1) deskripsi data; 2) uji prasyarat analisis normalitas; 3) analisis jalur yang meliputi: analisis model regresi, pengujian hipotesis dan penentuan tingkat pengaruh.

\section{HASIL DAN PEMBAHASAN}

\section{Pengaruh langsung supervisi terhadap OCB guru.}

Berdasarkan hasil perhitungan koefisien jalur $\mathrm{p}_{31}=0,461$ dan koefisien korelasi $\mathrm{r}_{13}=0,572$. Dengan demikian terdapat pengaruh langsung positif supervisi terhadap OCB.

Hasil penelitian tersebut sesuai dengan konsep Paul E Spector (1997:57) yang mengatakan, "ocb is caused by good treatment from the supervisor and by job satisfaction". OCB disebabkan oleh mekanisme supervisi yang baik dan kepuasan kerja. Pendapat ini mengisyaratkan bahwa supervisi merupakan salah satu prediktor munculnya OCB, dimana supervisi memungkinkan supervisor membentuk dan mempengaruhi perilaku bawahan karena mereka bekerja dan bertatap muka dalam mengejar tujuan organisasi. Deckop mengatakan, "there is persuasive evidence that OCB is an outcome consistent with a social exchange relationship". Ada bukti persuasif bahwa OCB adalah hasil yang konsisten dengan pertukaran sosial.sedangfkan Todd mengatakan, "OCB can be affected by instilling in employees a perception of expertise in their job tasks". OCB dapat dipengaruhi dengan menanamkan pada karyawan persepsi keahlian dalam tugas pekerjaan mereka. Jones (2008:95) mengatakan, "organization citizenship behavior (OCB) is behavior that is above and beyond the call of duty that is behavior that is not required of organizational members but is nonetheless necessary for organizational survival and effectiviness". OCB adalah perilaku yang melebihi panggilan tugas di mana merupakan perilaku yang tidak di perlukan oleh anggota organisasi tetapi penting bagi kelangsungan hidup dan efektivitas organisasi. Robbins dan Coulter (2012:373) menyebutkan OCB sebagai, "organizational citizenship behavior $(O C B)$ is discretionary behavior that's not part of an employee's formal job requirements, but which promotes the effective functioning of the organization". OCB adalah perilaku memilih yang bukan bagian dari persyaratan kerja formal karyawan, tapi dapat mempromosikan fungsi efektif dari organisasi. Definisi yang sama juga dikemukakan Steve M. Jex (2002:114) yang mengatakan bahwa, "although it can take several forms, OCB is defined as behavior that is not part of employees' formal job responsibilities. Sedangkan Borders \& Brown (2005:71) mengatakan, "supervision is evaluative, there is a power differential in the relationship, and supervisees typically are quite invested, personally, in their work". Supervisi di maknai sebagai bentuk evaluatif, sehingga ada kekuatan yang diferensial dalam hubungan, dan di supervisi biasanya cukup di investasikan, secara pribadi, dalam pekerjaan mereka. Sullivan (2009:4) secara spesifik memaknai supervisi sebagai, "supervision is the process of engaging teachers in instructional dialogue for the purpose of improving teaching and increasing student achievement". Supervisi adalah proses melibatkan guru dalam dialog untuk meningkatkan pengajaran dan prestasi siswa. Sedangkan Bailey (2006:340) mendefinisikan supervisi, "supervision is a process of overseeing theability of people to meet the goals of the organization in which they work". Supervisi adalah proses mengawasi kemampuan orang untuk memenuhi tujuan organisasi di mana mereka bekerja. Kimbal 
Willes (1956:4) menyimpulkan supervisi: supervision exist to help teacher to do their jobs better". Supervise adalah untuk membantu guru melakukan pekerjaan yang lebih baik Hal in mencerminkan semakin baik mekanisme supervisi maka semakin baik OCB guru.

\section{Pengaruh langsung dukungan tugas (task support) terhadap OCB guru}

Berdasarkan hasil perhitungan koefisien jalur $\mathrm{p}_{32}=0,319$ dan koefisien korelasi $\mathrm{r}_{23}=0,479$. Dengan demikian terdapat pengaruh langsung positif dukungan tugas (task support) terhadap OCB guru.

Hasil penelitian tersebut sesuai dengan konsep Neustrom (2002:184) yang mengatakan, "there is a supervisor here in the western area who is the epitome of a leader the reason he cares. He cares about people (psychological support) and about getting the job done right (task support). His enthusiasm is real, not forced, and it's quite contagious. His employees want to work for him and learn from him. Dukungan tugas (task support) merupakan kepedulian supervisor terhadap pekerjaan karyawan, agar karyawan dapat melakukan pekerjaan dengan benar. Semakin tinggi tingkat kepedulian supervisor terhadap pekerjaan karyawan, maka antusiaisme karyawan dalam bekerja semakin nyata dalam melakukan pekerjaan secara sukarela. Sonnentag (2002:457) mengatakan, "when employers pursue normative contracts that signify a mutual investment approach by providing employees with significant training, career development opportunities, and job security in exchange for dedication and commitment, employees displayed high performance, commitment, citizenship, and trust. Ketika pengusaha mengejar kontrak normatif yang menunjukkan pendekatan investasi reksa dengan memberikan karyawan dengan pelatihan yang signifikan, kesempatan pengembangan karir, dan keamanan kerja dalam pertukaran untuk dedikasi dan komitmen, karyawan menampilkan kinerja tinggi, komitmen, citizenship, dan kepercayaan. Sonnentag mengutip pendapat (Ostroff, Bowen dan Locke). Antara lain sebagai berikut,

" however, lower task performance is only one of many possible responses to dissatisfaction (Ostroff $\mathcal{E}$ Bowen). Dissatisfied employees are more likely to file grievances, engage in sabotage, ask for a transfers, be absent, and fail to pass on important information (Locke). In contrast, satisfied employees tend to put more effort into their work, engage in a greater number of citizenship behaviors, demonstrate more consistent attendance, and make more suggestions on how to improve work procedures." Apabila kinerja tugas rendah maka hanya satu kemungkinan dari banyak tanggapan, yakni ketidak puasan. Karyawan yang tidak puas lebih mungkin untuk mengajukan keluhan, melakukan sabotase, meminta pindah, absen, dan tidak mau menyampaikan Informasi penting (Locke). Sebaliknya, karyawan yang puas cenderung lebih tekun dalam pekerjaan mereka, selalu menonjolkan perilaku citizenship, menunjukkan lebih konsisten kehadiran, dan lebih banyak memberi saran tentang cara meningkatkan prosedur kerja. Neustrom (2011:183) mengatakan, “...they provide task support when they help assemble the resources, budgets, power, and other elements that are essential to get the job done". Mereka memberikan dukungan tugas ketika mereka membantu menyediakan sumber daya, anggaran, kekuasaan, dan elemen lain yang penting untuk mendapatkan pekerjaan yang dilakukan. Sementara Faruk Şahin (2011:4), menyatakan bahwa : “...task support may also provide resources in the forms of materials, technology, or work equipment". Dukungan tugas juga dapat memberikan sumber daya dalam bentuk bahan, teknologi, atau peralatan kerja. Sedangkan Luthans (2011: 149) mendefinisikan OCB sebagai, “OCB as "individual behavior that is discretionary, not directly or explicitly recognized by the formal reward system, and that in the aggregate promotes the effective functioning of the organization". OCB sebagai perilaku individu yang bersifat bebas, yang tidak secara langsung dan eksplisit mendapat penghargaan dari sistem imbalan formal, dan yang secara keseluruhan mendorong keefektifan fungsi-fungsi organisasi. Jones (2008:95) mengatakan, "organization citizenship behavior (OCB) is behavior that is above and beyond the call of duty that is behavior that is not required of organizational members but is nonetheless 
necessary for organizational survival and effectiviness". OCB adalah perilaku yang melebihi panggilan tugas di mana merupakan perilaku yang tidak di perlukan oleh anggota organisasi tetapi penting bagi kelangsungan hidup dan efektivitas organisasi.

Melalui konsep dan teori-teori tersebut dapat dikatakan bahwa semakin baik dukungan tugas yang diterima guru maka semakin baik tingkat OCB guru.

\section{Pengaruh langsung supervisi terhadap dukungan tugas (task support)}

Berdasarkan hasil perhitungan koefisien jalur $p_{21}=0,347$ dan $r_{12}=0,347$.Dengan demikian terdapat pengaruh langsung positif kepemimpinan transformasional terhadap kompensasi.

Hasil penelitian tersebut sesuai dengan konsep, Sonnentag (2002:456) yang mengatakan, "supervisors can influence perceptions of organizational support by determining and distributing rewards, introducing subordinates to key individuals in other parts of the organization, providing access to resources and information, as well as offering career advice, work assignment, training opportunities, and emotional support". Supervisor dapat mempengaruhi persepsi dukungan organisasi dengan menentukan dan mendistribusikan hadiah, mengenalkan bawahan kepada individu lain dalam organisasi, menyediakan akses, sumber daya dan informasi, serta memberi nasihat untuk pengembangan karir, tugas kerja, kesempatan pelatihan, dan dukungan emosional.

Sergiovani dan Starrat (2002:5) menjelaskan, "principals and other formal supervisors, therefore, have two broad responsibilities. To provide the most effective supervision they can for teachers, and to provide the conditions, help and support teachers need to engage in the supervisory functions for themselves as part of their daily routine. Kepala sekolah dan supervisor formal lainnya, memiliki dua tanggung jawab yang luas, yaitu untuk memberikan supervisi yang paling efektif sebisa mereka untuk guru, dan Untuk menyediakan kondisi, bantuan dan dukungan untuk keperluan guru yang perlu melibatkan fungsi supervisi. Sonnentag (2002:456) mengatakan: "Leadership and supervision also can impact the nature of the exchange relationship that employees share with the organization". Kepemimpinan dan supervisi juga dapat mempengaruhi hubungan interaksi karyawan dengan organisasi

Hal ini mencerminkan semakin baik mekanisme supervisi maka semakin baik pula dukungan tugas (task support).

\section{PENUTUP}

Kesimpulan. Berdasarkan hasil data penelitian dan hasil analisis data penelitian yang telah dibahas bab IV, dengan semua persyaratan analisis data yang meliputi uji linieritas serta keberatian regresi telah dipenuhi, maka dapat diambil beberapa kesimpulan sebagai berikut : (1) Terdapat pengaruh langsung supervisi terhadap OCB. Artinya jika makin baik pelaksanaan supervisi, akan mempengaruhi perilaku maupun ekspresi guru dalam menjalankan tugasnya, sehingga semakin baik supervisi maka OCB guru semakin baik. (2) Terdapat pengaruh langsung dukungan tugas (task support) terhadap OCB. Artinya jika makin tersedia alat, bahan, jasa dan sumber daya yang dibutuhkan guru dalam melakukan pekerjaan, maka OCB guru semakin baik.. (3) Terdapat pengaruh langsung kemampuan teknologi informasi dan iklim sekolah. Artinya makin baik pelaksanaan supervisi maka dukungan tugas (task support) semakin baik. 
Saran. Berdasarkan kesimpulan hasil penelitian diatas, maka disarankan (1) Pemerintah Kabupaten Halmahera Selatan, melalui Dinas Pendidikan dan Kebudayaan agar menetapkan kebijakan tentang perlu adanya kesadaran dalam diri kepala sekolah akan pentingnya peningkatan mutu pendidikan yang dalam hal ini dapat ditingkatkan melalui peningkatan kualitas supervisi. Selain itu dalam rekrutmen guru perlu memperhatikan aspek kompetensi, penempatan dan reward yang dapat memicu munculnya OCB. (2) Kepala sekolah untuk meningkatkan fungsi supervisi dan memberikan dukungan tugas (task support) yang maksimal, dengan menyediakan bahan yang diperlukan guru dalam menjalankan tugas, menyediakan alat yang diperlukan guru dalam melakukan pekerjaan, memberikan jasa yang sesuai dan meningkatkan sumber daya guru kearah yang lebih baik, maka guru akan membalas dengan tindakantindakan positif yang mengarah pada pembentukan OCB. (3) Para guru agar selalu menunjukan kinerja profesional dalam melaksanakan tugas dan tanggung jawab yang mengacu pada kompetensinya. (4) Para peneliti agar menindak lanjuti penelitian ini melalui penelitian-penelitian serupa, dengan mengembangkan variabel-variabel bebas, jumlah responden dan cakupan wilayah penelitian. Hal ini disebabkan masih banyak faktor yang mempengaruhi serta berhubungan dengan OCB selain supervisi dan dukungan tugas (task support), dan tentunya karakteristik responden dari wilayah penelitian yang beragam menjadi bahan perbandingan dengan tesis yang penulis buat. 


\section{DAFTAR RUJUKAN}

Bailey Kathleen M, Language Teacher Supervision: A Case-Based Approach (New York: Cambridge University Press, 2006)

Borders L. DiAnne \& Brown Lori L., The New Handbook of Counseling Supervision (New Jersey: Lawrence Erlbaum Associates,2005)

Budiharjo Andreas, Menuju Pencapaian Kinerja Optimum, Sintesis teori untuk mengungkap kotak hitam organisasi (Jakarta: Prasetya Mulya Publishing, 2011)

Caruso, Supervision in Early Childhood Education: A Developmental Perspective (New York: Teachers College, 2007)

Cassidy Carlene dan Kreitner Robert, Supervision Setting People up for Success (USA: South-Western Cengage Learning, 2010)

Colquitt/LePine/Wesson,Organizational Behavior, Improving Pervormance and commitment in the workplace (New York: McGraw Hill, 2011)

Faruk Şahin, The interaction of self-leadership and psychological climate on job performance (African Journal of Business Management Vol. 5(5), 4 March, 2011, ISSN 1993-8233 (C)2011 Academic

Jones Gareth, Organizational Theory, Design and Change (New Jersey: Pearson Prentice Hall, 2010)

Kimbal Willes, Supervision In Phisical Education (USA: Prentice-Hall, 1956)

Luthans Fred, Organizational Behavior, An Evidence-Based Approach Twelfth Edition (New York: McGraw-Hill Companies, 2011)

Newstrom, Organizational Behavior,human behavior at work, thirteent edition (New York: Mc Graw Hil, 2011

Robbins \& Coulter. Management Eleventh Edition (New York: Prentice-Hall, 2012)

Sergiovanni T.J. and Starratt Robert J., Supervision, A Redefinition, Seventh edition (New York : Mc Graw Hill, 2002)

Sonnentag Sabine, Psychological Management of Individual Performance (New Yor: Wiley Editorial Offices, 2002)

Sullivan Susan, Supevision That Improves Teaching and Learning Strategies and Techniques (California: Corwin a sage Company, 2009) 